\title{
Canada and the First World War - Thirteen Years On: An Introduction to the Second Edition
}

\author{
DAVID MACKENZIE
}

It has been a little more than a dozen years since the publication of the first edition of Canada and the First World War, and it is a pleasure to have our work made available again in this new, second edition. We believed at the time that it was impossible to study the history of modern Canada without taking into consideration the experience of the First World War and that it was time to reappraise the war and its impact on Canadian society. We approached our topics each in our own way but took as a starting point the questions of national transformation and nation building. Did Canada emerge from the war as a "nation transformed" - economically, socially, internationally - and, if so, in what ways? Not surprisingly we found the idea of "transformation" difficult to define and clearly very uneven in its application. For such a diverse nation, in terms of region, class, ethnicity, language, and gender, there might be no other possible outcome.

Transformation and nation building remain common themes in modern Canadian writing on the war. The war is still regularly portrayed as part of a "coming-of-age" story, in spite of all the death, destruction, and social upheaval that accompanied it. The war was a test of fire and Canada came through a stronger and more modern and independent country. Others continue to challenge these conclusions and expose the great regional, class, racial, and gender divisions that the war exacerbated. The historiographical divisions remain as well, on ideological grounds, and between social and political historians, national and regional perspectives, and academic and popular history. In a thoughtful essay in the Canadian Historical Review, military historian Mark Osborne Humphries has called for greater effort to bridge these 


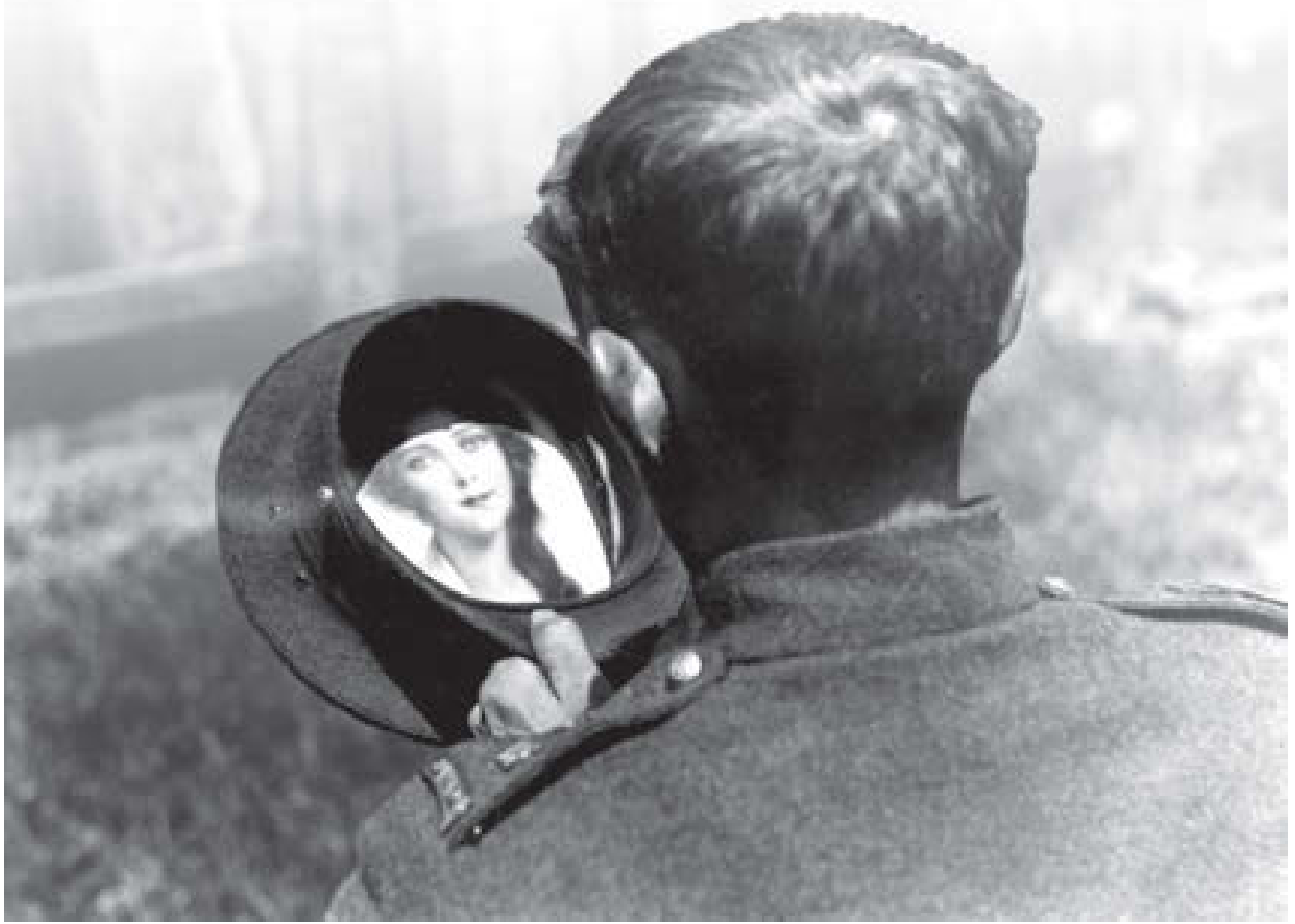

Tip top lady for soldiers: soldier with girl's picture in his hat, 1916, Courtesy City of Toronto Archives, fonds 1244, item 829. 
divides. ${ }^{1}$ Military historians need to address questions of power, race, class, and gender, while social historians need to recognize the transformative aspects of the war on a personal as well as a national level. Has progress been made on the integration of these different perspectives on the war? The publication of this second edition provides an opportunity to assess how Canadians have written about the Great War since this book first appeared in 2005.

\section{Fighting the War}

That we witnessed an increase in interest in the First World War as its centenary approached is not that surprising, but by any measure it has been a very productive dozen years. Still, we have not seen the outpouring of general histories of Canada's war that might have been expected, with Brian Tennyson's Canada and the Great War being the one major exception. ${ }^{2}$ Tennyson speculates on why there have been so few surveys of the war experience and suggests that it is partly because the war has been such a divisive issue in Canada - between French and English, rural and urban, and working- and middle-class Canadians. Tennyson's book was also published in the United States and is aimed at an international (American) audience and therefore contains a fair amount of background information on Canada-United States relations. Nevertheless, he questions the colony-to-nation theme, positing that Canada was neither a colony in 1914 nor a nation in 1918, and argues that the key importance of the war was that it reordered relations with the United States. Increased military cooperation, more investment and trade, and the inundation of American popular culture combined to make the war a dividing point and, in the process, turned Canada into a North American nation.

While there are few recent survey histories of Canada's war, there has been much more attention focused on the writing of the history of Canada's war. Tim Cook's Clio's Warriors is a detailed study of Canada's early official historians - those who were authorized to write

1 Mark Osborne Humphries, "Between Commemoration and History: The Historiography of the Canadian Corps and Military Overseas, Canadian Historical Review 95, no. 3 (September 2014): 384-97.

2 Brian Douglas Tennyson, Canada's Great War, 1914-1918: How Canada Helped Save the British Empire and Became a North American Nation (Lanham, MD: Rowan and Littlefield Publishers, 2015). 
the history and protect the memory of the war. They defended this memory against all critics - domestic and foreign - and protected the reputations of those who fought the war. They also guarded the documentary record and acted as gatekeepers to those others who wished to gain access. In particular, Cook focuses on the first official historian, Colonel A. F. Duguid, who saw himself as the "guardian of the CEF's reputation," and he explains why it took Duguid so long to produce a single volume of a projected twelve-volume official history. ${ }^{3}$

These early historians produced nationalistic history, and it was here that the colony-to-nation idea emerged. Duguid purposely built up the role of the Canadian citizen soldiers and emphasized their inventiveness, resiliency, and frontier background (even though a great many were urban dwellers and British born), which set them apart from their British cousins. This idea of the amateur citizen soldier is also the focus of James Wood's Militia Myths. In a much more critical way, Wood examines how Canadians thought and wrote about citizen soldiers and how the war and conscription challenged their preconceived notions. ${ }^{4}$

Nationalism was woven into the writing of official histories, getting the record straight, achieving recognition and autonomy, and defending Canada against unfair criticism in British and American histories. The death and destruction of the war was not ignored, but thanks to the sacrifice, courage, and performance of the Canadian Expeditionary Force (CEF) in France, Canadians could take pride and find some meaning in their efforts. But, as Wesley Gustavson reminds us, Duguid and others did all this without shedding their British heritage or commitment to the empire. Duguid's rising nationalism was consistently expressed "within an imperial or British framework." ${ }^{15}$ It would be other historians who would take the Britishness out of the equation.

Official history became more professionalized by the late twentieth century, less bureaucratic, and more focused on the experience of the soldiers themselves. Military history was also no longer the sole

3 Tim Cook, Clio's Warriors: Canadian Historians and the Writing of the World Wars (Vancouver: UBC Press, 2006), 49. See also Cook, "Quill and Canon: Writing the Great War in Canada," American Review of Canadian Studies 35, no. 3 (October 2005): 522.

4 James Wood, Militia Myths: Ideas of the Canadian Citizen Soldier, 1896-1921 (Vancouver: UBC Press, 2010).

5 Wesley C. Gustavson, "Competing Visions: Canada, Britain, and the Writing of the First World War," in Canada and the British World: Culture, Migration, and Identity, ed. Philip Buckner and R. Douglas Francis (Vancouver: UBC Press, 2006), 148. 
preserve of the official historians, as new generations of academic historians - including Desmond Morton, J. L. Granatstein, Tim Cook, Bill Rawling, and others - came to study the war, exploring areas such as trench warfare, the use of gas, propaganda, prisoners of war, veterans, and soldiers and their families. More recently, it has been embraced by a growing collection of scholars who have built on the early work of these official and professional historians. ${ }^{6}$ At the same time, the study of French Canada's role in the military history of the war has expanded beyond the few early studies on the 22nd Regiment and/or conscription and the War Measures Act. ${ }^{7}$

In particular, Tim Cook has emerged as a pre-eminent military historian with a series of books and articles on all aspects of the war effort including his superb, award-winning, two-volume study of the front-

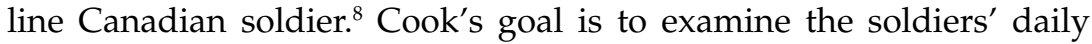
lives and to trace the Canadian Corps' evolution into an elite fighting force. "It was the infantry," he writes, "who fought and died for the shattered and cratered geography of No Man's Land. And through the blood test of battle, it was these soldiers at the sharp end of war those ordinary Canadians called upon to perform the extraordinary who ultimately defeated the German armies, forever changing world history." 9 Using an impressive array of sources, Cook brings the reader into the trenches to explore what it meant to be a soldier - what they wore, saw, read, sang, ate, and drank - as they worked, waited, and fought in the mud of France and Belgium for more than three years.

Nation building is here too, with the CEF standing in for Canada and coming of age in the mud and stench of battle. Years of tough experience, by learning from their mistakes, and through innovation and sheer determination, the Canadians overcame their lack of training,

6 Andrew Iarocci, "Writing on the Great War at the Centenary: Recent Books on Canada's First World War," Journal of Canadian Studies 49, no. 3 (Fall 2015): 256-67. See, for example, William Johnston, William Rawling, Richard Gimblett, and John MacFarlane, The Seabound Coast: The Official History of the Royal Canadian Navy, vol. 1, 1867-1939 (Toronto: Dundurn, 2011).

7 Mourad Djebabla, "Historiographie francophone de la première guerre mondiale: Écrire la grande guerre de 1914-1918 en français au Canada et au Québec," Canadian Historical Review 95, no. 3 (September 2014): 407-16.

8 Tim Cook, At the Sharp End: Canadians Fighting the Great War 1914-1916 (Toronto: Penguin Canada, 2007); and Shock Troops: Canadians Fighting the Great War 1917-1918 (Toronto: Penguin Canada, 2008).

9 Cook, At the Sharp End, 7. 
their early defeats, and their "colonial" status to become one of the elite forces on the Western Front - much as Canada emerged from the war a stronger, more self-confident, more respected, and more independent nation. It wasn't always smooth sailing either, and Cook details the difficulties, obstacles, and mistakes in the long learning curve in raising, transporting, training, and maintaining the CEF in the field. The Canadians survived, adapted, and emerged as "shock troops" to play a major role in the last One Hundred Days, the final offensive that brought the war to a close. Coming in at well over a thousand pages, these two volumes represent the most thorough, detailed, and painstakingly researched examinations of Canada's war in many years.

More focused but equally valuable studies have appeared on individual military units. In Shoestring Soldiers, Andrew Iarocci examines the training and deployment of the 1st Division from when it was the only Canadian division serving in France through its action in the Second Battle of Ypres in 1915. His goal is to establish the reputation of the division as it evolved into "an effective combat organization, one that made a vital contribution to the Allied cause. ${ }^{\prime 10}$ Others have examined particular battalions, regiments, and individuals; Captain Robert Clements, who served in the 25th Battalion throughout the war, wrote his unit's story in Merry Hell, while Roger Gunn has examined the life of one of Canada's greatest First World War aces - Nanaimo's Raymond Collishaw - as a pilot and squadron leader. ${ }^{11}$ Geoff Keelan takes a slightly different tack in "Il a bien merité de la patrie" as he examines the experience of the CEF's only French-Canadian battalion at the Battle of Courcelette. Rather than detailing the battalion's actions, Keelan focuses on how it has been remembered or, in this case, forgotten in Quebec, where the achievements of French-Canadian soldiers have been overshadowed by a "carefully constructed story of oppression

10 Andrew Iarocci, Shoestring Soldiers: The 1st Canadian Division at War, 1914-1915 (Toronto: University of Toronto Press, 2008), 10. See also Kenneth Radley, We Lead, Others Follow: First Canadian Division, 1914-1918 (St Catharines: Vanwell, 2006).

11 Captain Robert N. Clements, MC, Merry Hell: The Story of the 25th Battalion (Nova Scotia Regiment): Canadian Expeditionary Force 1914-1919, ed. Brian Douglas Tennyson (Toronto: University of Toronto Press, 2013); Roger Gunn, Raymond Collishaw and the Black Flight (Toronto: Dundurn, 2013). See also Timothy J. Stewart, Toronto's Fighting 75th in the Great War 1915-1919: A Prehistory of the Toronto Scottish Regiment (Queen Elizabeth the Queen Mother's Own) (Waterloo: Wilfrid Laurier University Press, 2017). 
and victimization."12 There was an irony at work here, as well, as the regiment's motto - je me souviens - became the provincial motto, but with the 22nd left out.

Equal attention has been devoted to important Canadian battles, if only in an effort to bring attention to landmark events other than Vimy Ridge. The Second Battle of Ypres, for example, in addition to the works mentioned above, has been the focus of two recent studies, one by Nathan Greenfield and the other by George Cassar. ${ }^{13}$ In addition, Douglas Delaney and Serge Marc Durflinger's Capturing Hill 70 shifts the historical spotlight on to the key August 1917 battle that was soon overshadowed by Vimy, Passchendaele, and Ypres. With the support of the Hill 70 Memorial, the editors brought together a distinguished group of scholars to set the record straight. Hill 70 was the CEF's first major battle under the command of a Canadian - Lieutenant General Sir Arthur Currie. Individual chapters examine the details of the battle, the commanders, the enemy, the political turmoil, and explore the question of how the battle got lost in our memory of the war. "That it was temporally and geographically wedged between the Canadian commemorative pillars of Vimy (April 1917) and Passchendaele (October-November 1917)," writes one of the editors, "perhaps helps explain any public or official neglect of the battle."14 Together this collection goes a long way in restoring Hill 70 to its rightful place in Canadian military history. ${ }^{15}$

J. L. Granatstein takes aim directly at Vimy in The Greatest Victory, which follows the CEF through the last hundred days of the war as the Canadians fought their way through Amiens, the Canal du Nord, Valenciennes, and into Mons and the ultimate defeat of Germany in November 1918. It is a brisk and absorbing look at this climatic moment in the war; but the battle was also very costly, with Canada suffering

12 Geoff Keelan, "'Il a bien merité de la patrie': The 22nd Battalion and the Memory of Courcelette," Canadian Military History 19, no. 3 (2010): 30.

13 Nathan M. Greenfield, Baptism of Fire: The Second Battle of Ypres and the Forging of Canada, April 1915 (Toronto: Harper Collins, 2007); and George Cassar, Hell in Flanders Fields: Canadians at the Second Battle of Ypres (Toronto: Dundurn, 2010).

14 Douglas E. Delaney and Serge Marc Durflinger, eds., Capturing Hill 70: Canada's Forgotten Battle of the First World War (Vancouver: UBC Press, 2016), 226.

15 There are also recent guides to the battlefields, published in advance of the centenary: see Susan Evans Shaw, Canadians at War, vol. 1, A Guide to the Battlefields and Memorials of World War I (Fredericton: Goose Lane Editions, 2011); and Frank Gogos, The Royal Newfoundland Regiment in the Great War: A Guide to the Battlefields and Memorials of France, Belgium, and Gallipoli (St John's: Flanker Press, 2015). 
about 20 per cent of its total casualties for the war. Granatstein's goal, as suggested by the book's title, is to argue that the One Hundred Days though largely forgotten or unknown by Canadians today - was "unquestionably Canada's greatest contribution to the Allied victory," even more important than Vimy Ridge. In fact, he continues, it was the most important role Canadians ever played in battle. ${ }^{16}$

An even less well-known episode is Canada's small part in the international incursion into Siberia near the end of the war. In From Victoria to Vladivostok, Benjamin Isitt sheds light on this often overlooked expedition of approximately four thousand Canadian soldiers into Siberia to help put down the Bolshevik Revolution and hopefully bring Russia back into the war. It was a deeply unpopular adventure, and Isitt hints that it has been ignored by historians because it was a clear military defeat. The federal government was motivated by anti-Bolshevism and the fear of revolution at home, while working class and labour opposition in British Columbia drew more inspiration from the Russian Revolution and opposed the expedition. Tensions between the two spilled into the streets of Victoria and elsewhere while increased labour militancy at home only served to heighten anxieties about Russia and the need to stop the spread of Bolshevism. The book is an intriguing mixture of social and military history. ${ }^{17}$

The administrative and organizational work behind the CEF is also the subject of two recent works: Richard Holt's Filling the Ranks and William Stewart's The Embattled General Sir Richard Turner. Holt examines the crucial tasks of recruitment, training, transporting, and reinforcement of Canadian military personnel. The logistics of war is the focus here as Holt traces the evolution of Canada's manpower policy that, despite its lack of coherence, helped build the CEF into the professional and elite formation that it became. ${ }^{18}$ Stewart's goal is to challenge Turner's reputation as an ineffective and mediocre commander, and he goes a long way to set the record straight. Turner was the most senior

16 J.L. Granatstein, The Greatest Victory: Canada's One Hundred Days, 1918 (Toronto: Oxford University Press, 2014), xi.

17 Benjamin Isitt, From Victoria to Vladivostok: Canada's Siberian Expedition, 1917-19 (Vancouver: UBC Press, 2010). For the Victoria mutiny, see Isitt's "Mutiny from Victoria to Vladivostok, December 1918," Canadian Historical Review 87, no. 2 (June 2006): 223-64.

18 Richard Holt, Filling the Ranks: Manpower in the Canadian Expeditionary Force, 1914-1918 (Montreal: McGill-Queen's University Press, 2017). 
Canadian officer throughout the war and led the 2nd Division before becoming commander of the Canadian forces in England, and Stewart concludes that Turner was "charismatic, courageous, conscientious, capable, engaging, modest, and in the trenches. ${ }^{119} \mathrm{He}$ also offers a new perspective on Turner's often tense relationship with the much betterknown Arthur Currie. ${ }^{20}$

The opening of the official records and personnel files of the Canadian military has likely had its greatest impact on the scholarly examination of the individual soldier. In the last two decades a relatively small group of historians has done extraordinary work in examining the daily lives of soldiers, the problems they faced, and how they negotiated their surroundings in extreme and unimaginable contexts. Others have devoted considerable attention to how the Canadian military authorities responded to the important but relatively rare incidences of cowardice, desertion, and self-inflicted wounds. Many of these scholars have published in the journal Canadian Military History, and credit must go to the journal's editors for their work over the past dozen years.

Mark Humphries has examined self-inflicted wounds and how they were perceived as a challenge to the power structure of the military and how, in a small way, they gave soldiers a little more control over their own bodies. Self-inflicted injuries were one way to escape from the trenches and, in response, they were perceived by the military authorities as both a form of cowardice and an attempt to undermine military sovereignty. But Humphries argues that because a self-inflicted injury could be easily denied as an accident and was difficult to prove, the result in many cases was acquittal for the soldier. ${ }^{21}$ The effectiveness of military justice has also been explored by Teresa Iacobelli in "Arbitrary Justice?" and more fully in Death or Deliverance: Canadian

19 William F. Stewart, The Embattled General: Sir Richard Turner and the First World War (Montreal: McGill-Queen's University Press, 2015), 262.

20 On Currie, see Mark Osborne Humphries, ed., The Selected Papers of Arthur Currie: Diaries, Letters, and Report to the Ministry, 1917-1933 (Waterloo: Wilfrid Laurier University Press, 2008).

21 Mark Humphries, "Wilfully and With Intent: Self-Inflicted Wounds and the Negotiation of Power in the Trenches," Histoire sociale / Social History 47, no. 94 (June 2014): 369-97. 
Courts Martial in the Great War. Iacobelli notes that some 89 per cent of all death sentences were commuted, and she looks for patterns to help explain how and why this happened. Instead of patterns she finds randomness and inconsistency and notes that the timing of the court martial had as much as anything else to do with the decision to commute these death sentences. ${ }^{22}$

Tim Cook has solidified his reputation as a leading historian of the war in a series of articles on aspects of the lives of the front-line soldier. Most of the work looks at how these soldiers learned to cope within a context of extraordinary violence and destruction. In many cases these efforts to "normalize" their surroundings came in the guise of giving the trenches homelike qualities: naming them; using graffiti; exchanging postcards, cartoons, and drawings; and singing, reading, letter writing, or what he calls the "creation and consumption of culture." ${ }^{23}$ In other articles his subjects range from the songs that the soldiers sang and the souvenirs they collected to the role of the anti-hero in soldiers' culture and the killing of prisoners. ${ }^{24}$ In a similar way, Jason Wilson has added to our understanding of how the soldiers were entertained through "concert parties" staged by the Dumbells and other comedic troupes. The goal was not just to entertain; rather, it was all in an effort to raise the morale of the soldiers, to help them not only win the war but also to survive it as well..$^{25}$

22 Teresa Iacobelli, Death or Deliverance: Canadian Courts Martial in the Great War (Vancouver: UBC Press, 2013); and "Arbitrary Justice? A Comparative Analysis of Canadian Death Sentences Passed and Commuted during the First World War," Canadian Military History 16, no. 1 (Winter 2007): 23-36.

23 Tim Cook, "Spacial Sanctuaries and Normalizing Violence: The Canadian Soldier on the Western Front during the Great War," Journal of Canadian Studies 49, no. 3 (Fall 2015): 6.

24 Tim Cook, "The Politics of Surrender: Canadian Soldiers and the Killing of Prisoners in the Great War," Journal of Military History 70, no. 3 (2006): 637-65; "Anti-heroes of the Canadian Expeditionary Force," Journal of the Canadian Historical Association 19, no. 1 (2008): 171-94; "The Singing War: Soldiers' Songs in the Great War," American Review of Canadian Studies 39, no. 3 (2009), 224-41; "Black-Hearted Traitors, Crucified Martyrs, and the Leaning Virgin: The Role of Rumor and the Great War Canadian Soldier," in Finding Common Ground: New Directions in First World War Studies, ed. Michael Neiberg and Jennifer Keene (Leiden, the Netherlands: Brill Academic, 2012), 21-42; "'Tokens of Fritz': Canadian Soldiers and the Art of Souveneering in the Great War," War and Society 31, no. 3 (2012): 211-26.

25 Jason Wilson, Soldiers of Song: The Dumbells and Other Canadian Concert Parties of the First World War (Waterloo: Wilfrid Laurier University Press, 2012). 
The almost three thousand nursing sisters who served as officers in the Canadian Army Medical Corps, and nursing more generally, has received much more attention in the last decade. Cynthia Toman's Sister Soldiers details who they were, where they came from, where they served, and how they functioned within the Canadian military medical system. Her book is filled with individual stories of nurses and how they tried to live and work in the midst of artillery bombardment, bad weather, unbearable conditions, and disease. Using accounts left by the nursing sisters themselves, she assesses the impact of the war on these women and the nursing profession, even as they were being quickly dismissed once the war had come to an end. ${ }^{26}$

Our understanding of the war has also been broadened by new examinations of how the war was experienced by those who were either forced into the military or rejected by the military. Patrick Dennis has explored the approximately twenty-four thousand conscripts who fought (and died) in the CEF in the last year of the war. He challenges the idea that conscription was a mistake and a failure; indeed, these soldiers played a crucial role in the Hundred Days and, despite the insults and degradation they suffered, they were effective front-line soldiers. These conscripts were not a reluctant minority, Dennis reminds us, as they were selected from the majority of Canadian-born men who chose not to enlist. ${ }^{27}$ On the other side, Nic Clarke looks at the tens of thousands of men who were rejected for service in the CEF for various reasons, including a weak heart, bad lungs, flat feet, poor teeth, substandard eyesight, being too short, or having too small a chest. ${ }^{28}$ Astonishingly, up to 20-25 per cent of the men in the First Contingent raised in the first few weeks of the war were rejected as unfit. ${ }^{29}$ As Clarke points out, in the great majority of cases these rejected volunteers were excluded for

26 Cynthia Toman, Sister Soldiers of the Great War: The Nurses of the Canadian Army Medical Corps (Vancouver: UBC Press, 2016). See also Andrea McKenzie, ed., War-Torn Exchanges: The Lives and Letters of Nursing Sisters Laura Holland and Mildred Forbes (Vancouver: UBC Press, 2016), and Debbie Marshall, Give Your Other Vote to the Sister: A Woman's Journey into the Great War (Calgary: University of Calgary Press, 2007).

27 Patrick M. Dennis, Reluctant Warriors: Canadian Conscripts and the Great War (Vancouver: UBC Press, 2017).

28 Nic Clarke, Unwanted Warriors: The Rejected Volunteers of the Canadian Expeditionary Force (Vancouver: UBC Press, 2015).

29 On the first contingent specifically, see Nic Clarke, "'You Will Not Be Going to This War': The Rejected Volunteers of the First Contingent of the Canadian Expeditionary Force," First World War Studies 1, no. 2 (October 2010): 161-83. 
reasons that were invisible to the general public, leading to some social problems and anxieties in their dealings with other Canadians.

The issue of enlistment continues to attract scholarly attention. In two important articles, Jean Martin has brought into question the rate of participation of francophones in the Canadian military. In the first, he argues that the original estimate of approximately thirty to thirtyfive thousand francophones has been greatly underestimated because it focused exclusively on Quebec and did not fully consider the number of francophones who enlisted from other provinces. In the second, he examines the database containing all the names of recruits beginning with the letter ' $\mathrm{B}$ ' (comprising approximately 10 per cent of the CEF) and estimates the number of francophones in the military in the seventy to seventy-nine thousand range. This means that francophones comprised a significant proportion of the total CEF, and, if one considers only those who were Canadian-born (like virtually all francophone recruits), francophones comprised an estimated 17 per cent of the Canadian military. Why have these numbers been overlooked? "English-Canadian historiography convinced itself that it was natural that French-Canadians show no great support for the war effort of the British Empire, while French-speaking historians eagerly adopted the idea that Quebecers rejected participation in the war because of their innate pacifism," Martin argues. ${ }^{30}$

In addition, Peter Broznitsky, by focusing on the enlistment in the CEF of the three to four thousand Ukrainians from Russia and the Austro-Hungarian Empire, provides a close examination of the actual forms filled out by recruits and the confusion inherent in the records kept by the Canadian military. ${ }^{31}$ Elsewhere, Noah Riseman and Timothy Winegard have examined the change in government policy regarding the enlistment of Indigenous peoples and note that it was not only the falling number of volunteers that produced this change but also

30 Jean Martin, "Francophone Enlistment in the Canadian Expeditionary Force, 1914-1918," Canadian Military History 25, no. 1 (2016): 11; and “La participation des francophones dans le corps expéditionnaire canadien (1914-1919): Il faut réviser à la hausse," Canadian Historical Review 96, no. 3 (September 2015): 405-23. See also Jonathan Vance's research note, "Provincial Patterns of Enlistment in the Canadian Expeditionary Force," Canadian Military History 17, no. 2 (Spring 2008): 75-8.

31 Peter Broznitsky, "For King, Not Tsar: Identifying Ukrainians in the Canadian Expeditionary Force, 1914-1918," Canadian Military History 17, no. 3 (Summer 2008): 21-30. 
pressure from the British government to more actively recruit Indigenous men into the CEF.32

Work has also begun on the study of "boy" soldiers - the thousands of underage Canadians who volunteered to fight - likely in response to the recent attention paid to child soldiers being used and abused in conflicts around the world. Historians are forced to grapple with the question of what it meant to be a child in early twentieth century Canada and when did adulthood begin. In books aimed at the general reader, by Dan Black and John Boileau on Canada and Gary Browne on Newfoundland, the stories of these individual teenagers in war are told..$^{33}$ A shorter and more scholarly introduction to this topic by Tim Cook estimates that up to twenty thousand members of the CEF were underage and lied about their age. ${ }^{34}$

Some of the most interesting new research has been in the area of mental illness - how it was diagnosed and treated in the military. Mark Humphries and Kellen Kurchinski have looked at the nearly ten thousand Canadian soldiers diagnosed with shell shock and their treatment at two Canadian army hospitals set up in England, and they conclude that, however difficult to diagnose, these men were treated relatively humanely. ${ }^{35}$ Humphries has also taken the story into the Depression where he examines the efforts of several thousand veterans to receive compensation for the psychological injuries suffered during the war. Proving that their trauma was related to their military service was difficult, especially as the medical profession viewed these injuries through gendered lenses, often assessing them as the product of a

32 Noah Riseman and Timothy C. Winegard, "Indigenous Experience of War (Dominions)," in 1914-1918 Online: International Encyclopedia of the First World War, ed. Ute Daniel, Peter Gatrell, Oliver Janz, Heather Jones, Jennifer Keene, Alan Kramer, and Bill Nasson, issued by Freie Universität Berlin, https: / / encyclopedia.1914-1918online.net/home/. See also Timothy C. Winegard, Indigenous Peoples of the British Dominions and the First World War (New York: Cambridge University Press, 2011).

33 Dan Black and John Boileau, Old Enough to Fight: Canada's Boy Soldiers in the First World War (Toronto: Lorimer, 2013); and Gary F. Browne, Forget-Me-Not: Fallen Boy Soldiers: Royal Newfoundland Regiment, World War One (St John's: DRC Publishing, 2010).

34 Tim Cook, "'He Was Determined to Go': Underage Soldiers in the Canadian Expeditionary Force," Histoire sociale / Social History 41, no. 81 (May 2008): 41-74.

35 Mark Osborne Humphries with Kellen Kurchinski, "Rest, Relax and Get Well: A Re-conceptualization of Great War Shell Shock Treatment," War and Society 27, no. 2 (October 2008): 89-110. 
pre-existing condition and/or personal deviance rather than legitimate war injuries. "Real men did not break down," he writes, "nor did they allow their emotions to interfere with their manly duty as breadwinners and providers." ${ }^{36}$ Mental illness and shell shock among francophone soldiers has also been examined by Geneviève Allard, ${ }^{37}$ and Humphries has teamed up with Terry Copp to produce a broader collection, which contains original articles from Commonwealth sources. They set shell shock and battle exhaustion in a Commonwealth context and reveal how it was diagnosed and treated in Canada, Australia, New Zealand, South Africa, and Great Britain. ${ }^{38}$

One final area - Canada's international relations - has been relatively unexplored since 2005, beyond the peace negotiations and CanadianAmerican relations. One major exception is Paula Hastings, who, in "Territorial Spoils," looks at the wartime discussions over Canada's possible annexation of Britain's West Indian colonies. It was part of the evolving idea of empire with each of the dominions potentially taking on more responsibility for the colonial empire in their regions. Hastings situates the issue in the context of "racially inscribed projects" and the "increasingly fraught relations between white Canadians and West Indians of colour," and she shows how these relations "dampened interest in and ultimately quashed the possibility of federation by the fall of 1919." ${ }^{39}$ A deep division was revealed between Ottawa's vision of a quasi-colonial relationship with the West Indies as compared to the West Indian desire for provincial status. And, as West Indians learned of the treatment of black Canadians and, in particular, the treatment of West Indian students at Canadian universities, their support for any kind of union evaporated.

36 Mark Humphries, "War's Long Shadow: Masculinity, Medicine, and the Gendered Politics of Trauma, 1914-1939," Canadian Historical Review 91, no. 3 (September 2010): 530.

37 Geneviève Allard, Névrose et folie dans le corps expéditionnaire canadien (1914-1918): Le cas Québécois (Montréal: Athéna, 2012).

38 Terry Copp and Mark Osborne Humphries, Combat Stress in the 20th Century: The Commonwealth Experience (Kingston: Canadian Defence Academy Press, 2010).

39 Paula Hastings, "Territorial Spoils, Transnational Black Resistance, and Canada's Evolving Autonomy during the First World War," Histoire sociale / Social History 47, no. 94 (June 2014): 447. 


\section{The War at Home}

Political biography never goes out of style, but in recent years there have been few major biographies of key political figures, perhaps because so many central figures - including Robert Borden, Wilfrid Laurier, Arthur Meighen, Joseph Flavelle, John Dafoe, Clifford Sifton, Newton Rowell, and others - have already been well-served by their biographers. Two short biographies of the leading politicians of their day have appeared, although neither really breaks new ground with respect to the war. The first, André Pratte's Wilfrid Laurier, focuses little attention on political developments during the war, other than to add Pratte's criticism of Laurier's call for a referendum on conscription; it would have solved nothing, he concludes. ${ }^{40}$ Pratte suggests that if Laurier were in power instead of leader of the opposition he would have sought some kind of compromise to the political crisis, but he doesn't go so far as to suggest what that compromise would have looked like. The second, Martin Thornton's Robert Borden, was produced for a series on the making of the 1919 Versailles treaty. The book focuses on Borden's important but limited role at the Paris conference and Thornton is careful not to credit Borden with too much of an impact on the peace treaty ${ }^{41}$

Elsewhere, in a short chapter on Borden, Margaret MacMillan credits the prime minister for helping establish a new imperial relationship in which Canada maintained both autonomy and membership in a renewed empire, and she acknowledges Borden's work at the 1917 Imperial Conference and peace negotiations for some of this evolution. ${ }^{42}$ Finally, two new biographies of R. B. Bennett have appeared and, although neither is focused on the First World War, they demonstrate how Bennett's principles and personality worked against him during the war, leading to tension with the prime minister and Bennett's political marginalization. ${ }^{43}$

40 André Pratte, Wilfrid Laurier (Toronto: Penguin, 2011), 191-2.

41 Martin Thornton, Sir Robert Borden: Canada (London: Haus Publishing, 2010).

42 Margaret MacMillan, "Sir Robert Borden: Laying the Foundation," in Architects and Innovators: Building the Department of Foreign Affairs and International Trade, 1909-2009, ed. Greg Donaghy and Kim Richard Nossal (Montreal: McGill-Queen's University Press, 2009), 29-39. See also Tim Cook, "'Our First Duty Is to Win the War At Any Cost': Sir Robert Borden during the Great War," Journal of Military and Strategic Studies 13, no. 3 (Spring 2011): 1-24.

43 John Boyko, Bennett: The Rebel Who Challenged and Changed a Nation (Fredericton: Goose Lane Editions, 2010); and P. B. Waite, In Search of R. B. Bennett (Montreal: McGill-Queen's University Press, 2012). 
A few other figures have received biographical treatment. Norman Hillmer's admirable O. D. Skelton explains how Skelton's strong anti-conscription position - which arose from both his views of the empire and autonomy and his support for individual rights and selfdetermination, free of the constraints of an absolutist government - led him to maintain his support for Laurier when so many English-Canadian Liberals had deserted him. Deeply affected by Laurier's death soon after the war, Skelton shaped the second volume of his official biography of the former prime minister into "an explicit defence of national unity and an implicit plea for national reconciliation." ${ }^{44}$ In The Power of the Pen, Richard Clippingdale examines the life of newspaperman and political insider John Willison, editor of the financially troubled Toronto News. Willison's concern over "Quebec domination" and his adamant desire to see Laurier and the Liberals defeated at the polls brought him into politics where he played a minor but important and supportive role in the formation of the new Union Government and the federal election campaign of $1917.4^{45}$

Tim Cook has served up a double biography of Arthur Currie and Sam Hughes that follows the two protagonists - the war hero and the former minister of militia - through their individual wars to their ultimate and inevitable confrontation over their interpretation of the final days of the war, a confrontation that lasted beyond Hughes's death and ended in a courtroom in Cobourg, Ontario, in 1927. ${ }^{46}$ Hughes's accusation in the House of Commons that Currie had unnecessarily sacrificed the lives of some of his soldiers reignited the "war of reputations" and sparked one of the most sensational trials in Canadian history. Cook goes into elaborate detail about the two men's backgrounds and personalities, as well as their war and post-war experiences, to set the context. An earlier study on this court case by Robert Sharpe, first published in 1988, was reissued in 2009 as part of the Osgoode Society for Canadian Legal History and is focused directly on the trial, the issues, the evidence, and the people involved. ${ }^{47}$

44 Norman Hillmer, O. D. Skelton: A Portrait of Canadian Ambition (Toronto: University of Toronto Press, 2015), 67.

45 Richard Clippingdale, The Power of the Pen: The Politics, Nationalism, and Influence of Sir John Willison (Toronto: Dundurn, 2012).

46 Tim Cook, The Madman and the Butcher: The Sensational Wars of Sam Hughes and General Arthur Currie (Toronto: Allen Lane, 2010).

47 Robert J. Sharpe, The Last Day, the Last Hour: The Currie Libel Trial (Toronto: University of Toronto Press, 2009). 
Another important wartime figure was Quebec nationalist editor Henri Bourassa, and he has been the focus of several works by Geoff Keelan. In "Catholic Neutrality" Keelan sets Bourassa apart from most other Canadian wartime intellectuals in that he was one of the few to give serious consideration to the various offers of a negotiated peace to end the war. Whereas many Anglo-Canadians looked askance at any proposal short of total victory, Bourassa's greater scepticism and overriding desire for a quick end to the war made him seriously consider peace proposals, including those from Woodrow Wilson and Pope Benedict XV. Keelan portrays Bourassa as a "Catholic thinker" who espoused a position of "Catholic neutrality" and as one who put enormous faith in the pope to make the right decision or to sense the best course of action. All this made Bourassa "one of the most significant Canadian intellectuals during World War I." 48 Elsewhere, Keelan explores Bourassa's relationship with Talbot Papineau - their 1916 exchange of letters and failure to bridge the gap between Canada's two linguistic groups - as part of a case study in "cultural mobilization." 49

The last dozen years has seen the passing of the last survivors of the war and perhaps it is not surprising that this same period has seen the publication of numerous diaries, memoirs, and letters of those who experienced the war, either as soldiers at the front or those back home. ${ }^{50}$ Mélanie Morin-Pelletier looks at the correspondence of two soldiers one with his mother and the other with his wife back home. On one hand, there is a mixture of pride and anxiety and the desire to reassure and encourage those overseas, while on the other, a desire not to distress or overly concern those at home about the dangers at the front. She finds in these letters a blend of tenderness, hope, uncertainty, and disillusion about the war. ${ }^{51}$ There has also been a growing interest in

48 Geoff Keelan, "Catholic Neutrality: The Peace of Henri Bourassa," Journal of the Canadian Historical Association 22, no. 1 (2011): 123. For a new collection of Bourassa's writings, see Pierre Anctil, ed., "Do What You Must": Selected Editorials from Le Devoir under Henri Bourassa, 1910-1932 (Toronto: The Champlain Society, 2016).

49 Geoff Keelan, "Canada's Cultural Mobilization during the First World War and a Case for Canadian War Culture," Canadian Historical Review 97, no. 3 (September 2016): 377-403.

50 For a reference list of work produced by Canadian soldiers, see Brian Douglas Tennyson, The Canadian Experience of the Great War: A Guide to Memoirs (Lanham, MD: Scarecrow, 2013).

51 Mélanie Morin-Pelletier, “'The Anxious Waiting Ones at Home': Deux familles canadiennes plongées dans le tourment de la grande guerre," Histoire sociale / Social History 47, no. 94 (June 2014): 353-68. 
Quebec in the personal experiences of French Canadians who fought in the war, and Michel Litalien has recently published three edited collections - two memoirs and one collection of eyewitness accounts - of francophone soldiers in the CEF. ${ }^{52}$ Bill Parenteau and Stephen Dutcher have published the diaries of Daniel MacMillan, an average, Godfearing, hard-working, rural New Brunswicker. In a world of pigs, cows, and sheep, MacMillan's diaries give his perspective on the war, his early enthusiasm and patriotism, his volunteer work, his growing weariness by 1917, and how he faced the wounds and scars left over by the war. ${ }^{53}$

A fair amount has been published on the political history of the war, with conscription and the question of what French Canadians and Quebecers have chosen to remember (and what to forget) attracting considerable scholarly attention. ${ }^{54}$ Through an examination of textbooks (emanating primarily from central Canada) and Canadian novels, Andrew Theobald has looked at the way the conscription crisis has been retold over the years, and he makes the rather bold statement that the "conscription crisis is either ignored for the sake of Canadian nationalist unity or mythologized for the sake of Québec sovereignty demands." ${ }^{\prime 5}$ While the Anglo-nationalist viewpoint tends to emphasize

52 Honoré-Édouard Légaré, Ce que j'ai vu ... Ce que j'ai vécu, 1914-1916, ed. Michel Litalien (Montréal: Athéna, 2013); Georges-Ulric Francoeur, Mon journal: FranceBelgigue, 1915-1916 (Montréal: Athéna, 2011); and Écrire sa guerre: Témoignage de soldats canadiens-français, 1914-1919 (Montréal: Athéna, 2011).

53 Bill Parenteau and Stephen Dutcher, eds., War on the Home Front: The Farm Diaries of Daniel MacMillan, 1914-1927 (Fredericton: Goose Lane Editions, 2006). See also: Bryan Douglas Tennyson, ed., Percy Willmot: A Cape Bretoner at War, 1914-1919 (Sydney: Cape Breton University Press, 2007); L. Iris Newbold and K. Bruce Newbold, eds., "Without Fear and with a Manly Heart': The Great War Letters and Diaries of Private James Herbert Gibson (Waterloo: Wilfrid Laurier University Press, 2018); R. B. Fleming, ed., The Wartime Letters of Leslie and Cecil Frost, 1915-1919 (Waterloo: Wilfrid Laurier University Press, 2007); and Tim Cook and Natascha Morrison, "Longing and Loss from Canada's Great War," Canadian Military History 16, no. 1 (Winter 2007): 53-60.

54 See Mélanie Morin-Pelletier, "French Canada and the War (Canada)," and David MacKenzie, "Governments, Parliament and Parties (Canada)," both in 1914-1918 Online: International Encyclopedia of the First World War, ed. Ute Daniel, Peter Gatrell, Oliver Janz, Heather Jones, Jennifer Keene, Alan Kramer, and Bill Nasson, issued by Freie Universität Berlin, https:/ / encyclopedia.1914-1918-online.net/home/.

55 Andrew Theobald, "Divided Once More: Social Memory and the Canadian Conscription Crisis of the First World War," Past Imperfect 12 (2006): 18. 
the shared or unifying elements of the war, in Quebec it has become a story of resistance. Meanwhile, Desmond Morton has reviewed FrenchCanadian responses to the war and recruitment and seems to answer "no" to the question posed in his "Did the French Canadians Cause the Conscription Crisis of 1917?"56

Pervasive anti-Catholicism undoubtedly impacted the EnglishCanadian view of French Canadians as well as Irish Catholics, as demonstrated in two works by Kevin Anderson and Mark McGowan. ${ }^{57}$ McGowan in particular explores the difficulties facing Irish-Catholic Canadians during the war, when, despite the support of the church for the war effort and the enlistment of thousands of Irish Canadians, there still existed persistent anti-Catholicism or suspicion of the Irish thanks to age-old animosities, the actions of Irish nationalists during the war, French Catholics in Quebec, and the presence of thousands more Catholic Canadians from central and eastern Europe.

Taking a different perspective in his examination of the Protestant denominational press, Gordon Heath shows that, despite their enthusiastic endorsement of conscription and support for the war effort, the Protestant denominational press in English Canada saw an opportunity to promote "an understanding of French Canada" and became "a proponent of conciliation with Catholics in Quebec" by seeking out allies in French Canada who supported the war, including a few Catholic clergy in Quebec and among some French Canadians outside Quebec and Acadians in New Brunswick. ${ }^{58}$ Finding common ground for the foundations of a stronger nation was not always easy, but the Protestant denominational press tried to stay away from vociferous attacks on Quebec seen elsewhere in the Anglo press. Heath has also expanded on this topic with an edited collection of essays on how the various Christian churches reacted and contributed to the Canadian war effort. ${ }^{59}$

56 Desmond Morton, "Did the French Canadians Cause the Conscription Crisis of 1917?" Canadian Military History 24, no. 1 (Winter/Spring 2015): 89-99.

57 Kevin Anderson, "'The Cockroaches of Canada': French-Canada, Immigration and Nationalism, Anti-Catholicism in English-Canada, 1905-1929," Journal of Religious History 39, no. 1 (March 2015): 104-22; and Mark McGowan, The Imperial Irish: Canada's Irish Catholics Fight the Great War, 1914-18 (Montreal: McGill-Queen's University Press, 2017).

58 Gordon Heath, "The Protestant Denominational Press and the Conscription Crisis in Canada, 1917-1918," CCHA Historical Studies 78 (2012): 31.

59 Gordon L. Heath, ed., Canadian Churches and the First World War (Cambridge, UK: Lutterworth, 2014). 
In his comparison of Canada and Australia, Jatinder Mann argues that both countries came to see that conscription was necessary after their prime ministers had visited their troops at the front and both returned home determined to implement it. In Canada the debate hinged on identity and participation while in Australia the issue was more about which method - voluntary or compulsory - would be best to raise the necessary men. Mann argues that the voice of labour was stronger in Australia and thus the trade union movement and Labour Party were able to pressure the government into holding a referendum in which conscription was defeated. ${ }^{60}$

The introduction of conscription in 1917 set off one of the most tumultuous years in Canadian political history and it has been the focus of several historians. Tarah Brookfield, in "Divided by the Ballot Box," examines the attempted ouster of Dr Grace Ritchie-England, president of the Montreal Council of Women, for her outspoken opposition to conscription and the Wartime Elections Act that, among other things, enfranchised those Canadian women who had a close family relative in the war. In their failure to remove Ritchie-England, Brookfield exposes the important and varied differences among women on the social, political, and international issues of the day. And, in the process, she sheds light on how the dream of Canadian suffragists "that their participation as electors would revolutionize politics was shattered by the reality of women's diverse political interests and the compelling election propaganda surrounding their first opportunity to vote at the federal level." ${ }^{\prime 61}$

Borden's call for conscription was prompted by the high casualty rates from the battle of Vimy Ridge, argues Serge Durflinger in "Vimy's Consequence," and this announcement sparked riots and turmoil in Montreal and across Quebec, threatening the unity of the country. This circumstance made Vimy less the moment of national creation than is generally believed and, in fact, more "a potentially nation-destroying event." ${ }^{\prime 2}$ Patrice Dutil and David MacKenzie, in Embattled Nation, expand

60 Jatinder Mann, “'To the Last Man and the Last Shilling' and 'Ready, Aye Ready': Australian and Canadian Conscription Debates during the First World War," Australian Journal of Politics and History 61, no. 2 (2015): 184-200.

61 Tarah Brookfield, "Divided by the Ballot Box: The Montreal Council of Women and the 1917 Election," Canadian Historical Review 89, no. 4 (December 2008): 474.

62 Serge Marc Durflinger, "Vimy's Consequence: The Montreal Anti-conscription Disturbances, May to September 1917," in Turning Point 1917: The British Empire at War, ed. Douglas E. Delaney and Nikolas Gardner (Vancouver: UBC Press, 2017), 162. 
on this summer of unrest and examine the formation of the Union Government and how conscription played out in the divisive 1917 wartime election. In the first book on the "khaki" election, they closely examine the campaign, the impact of the military vote, and the effect of the Wartime Elections Act on Borden's victory at the polls. ${ }^{63}$ The introduction of conscription sparked some of the worst rioting of the war, including the deadly 1918 Easter riots in Quebec City. Martin Auger, in "On the Brink of Civil War," describes the rioting and explains how the federal government reacted forcefully-even overreacted-and clamped down severely on Quebec City, which was a major centre for industry and transportation. While there was little threat of actual revolution, Auger details how in the context of the emerging Red Scare, Canadian forces were kept in Quebec well after the war had come to an end. ${ }^{64}$

We are reminded, as well, that conscription was not just an issue between French and English Canadians and that there was opposition to conscription outside Quebec. Mourad Djebabla, in "Fight or Farm," surveys the resistance to conscription among farmers, an opposition that was less visible than among French Canadians and reflected a different sense of how rural Canada could contribute to the war effort rather than an expression of disloyalty. ${ }^{65}$ Andrew Theobald examines New Brunswick's response to conscription and notes that it "exposed complex tensions between rural and urban, liberal and conservative, north and south, Protestant and Catholic, as well as across the linguistic divide." 66

In a different vein, David Tough examines the introduction of the income tax in 1917 and the "conscription of wealth" rhetoric and sees in this debate a desire for a "break with the past." ${ }^{\prime 67}$ Amy Shaw has also

63 Patrice Dutil and David MacKenzie, Embattled Nation: Canada's Wartime Election of 1917 (Toronto: Dundurn, 2017).

64 Martin F. Auger, "On the Brink of Civil War: The Canadian Government and the Suppression of the 1918 Quebec Easter Riots," Canadian Historical Review 89, no. 4 (December 2008): 503-40.

65 Mourad Djebabla, "'Fight or Farm': Canadian Farmers and the Dilemma of the War Effort in World War I (1914-1918)," Canadian Military Journal 13, no. 2 (Spring 2013): 57-67.

66 Andrew Theobald, The Bitter Harvest of War: New Brunswick and the Conscription Crisis of 1917 (Fredericton, NB: Goose Lane Editions, 2008), 14-15.

67 David Tough, “'The Rich ... Should Give to Such an Extent That It Will Hurt': 'Conscription of Wealth' and Political Modernism in the Parliamentary Debate on the 1917 Income War Tax," Canadian Historical Review 93, no. 3 (September 2012): 382-407. 
looked at conscientious objectors who rejected conscription for ethical or religious beliefs. Exemptions were granted to those who could prove that they were a member of one of the "historic peace churches" - Mennonites, Hutterites, Doukhobors, and a few other groups - but anyone on the outside was vulnerable and could be exposed to harassment and even imprisonment. As Shaw explains, the government acted to keep a promise to some recognized conscientious objectors but not because it recognized any kind of individual right of conscience..$^{68}$

The repression of dissent is the focus of Brock Millman's Polarity, $\mathrm{Pa}$ triotism, and Dissent in Great War Canada.$^{69}$ The management of dissent is often overlooked by scholars, he argues, but all governments had to introduce some level of control of its population to maintain order at home while Canadians fought overseas. There was a kind of Goldilocks dilemma of finding that compromise between being too severe, which might have enflamed unrest, and too tolerant, which would likely have angered British Canada and might have permanently damaged national unity. British Canadians formed the government in Ottawa and they used their power to curb dissent among the others - French Canadians and those "new" or non-British Canadians. He argues that Ottawa acted in a heavy-handed way and suggests that this was a response to the demands of British Canadians who were determined to see the war through to victory whatever the cost. It is quite a different perspective than that found in Reg Whitaker, Gregory Kealey, and Andrew Parnaby's Secret Service. In their chapter on the war, these authors take a much more critical look at the government's reaction to rising socialism and labour militancy. ${ }^{70}$

Jonathan Vance's A History of Canadian Culture, although focused on far more than the First World War, contains one of the few new examinations of the cultural impact of the war. According to Vance, the war proved two things, that "Canadians were enthusiastic consumers of culture; and that their culture was derivative rather than distinctly

68 Amy J. Shaw, Crisis of Conscience: Conscientious Objection in Canada during the First World War (Vancouver: UBC Press, 2009), 165.

69 Brock Millman, Polarity, Patriotism, and Dissent in Great War Canada, 1914-1919 (Toronto: University of Toronto Press, 2016).

70 Reg Whitaker, Gregory S. Kealey, and Andrew Parnaby, Secret Service: Political Policing in Canada from the Fenians to Fortress America (Toronto: University of Toronto Press, 2012), 60-89. 
Canadian." ${ }^{\prime 71}$ The war, in turn, made way for a new generation of cultural producers who would go on to create a more distinctively Canadian culture in its wake. Moreover, an important wartime moment is documented in Gene Allen's Making National News, which clearly situates the creation of the Canadian Press (CP) in the wartime experience and concerns over the American focus of the Associated Press. A national news service became an increasing priority as problems of censorship, control of the news, and recruitment mounted. Here is community and nation building together, through $\mathrm{CP}^{\prime}$ 's national distribution of Canadian and international news stories. ${ }^{72}$ Moreover, the First World War continues to fascinate novelists, including recent work by Frances Itani, Jane Urquhart, and Joseph Boyden. As Neta Gordon demonstrates, novelists still wrestle with the themes of transformation and coming of age or at least see in the war the sources of some our most cherished "Canadian values." ${ }^{\prime 73}$ Likewise, in his examination of the war-related fiction of the later war and early post-war eras, Peter Webb demonstrates how the line between literature and propaganda was frequently crossed. ${ }^{74}$

The impact of the war on those who remained at home has probably received more attention than any other aspect of the war. The role of women and children, in particular, remains a constant focus of attention. In her review of recent literature, Amy Shaw suggests that we now have a more nuanced understanding of the experiences of women during the war. Newer methods, such as material history, and inventive ways have been utilized to overcome the obstacles created by the lack of good archival sources on women's activities. She is also critical of the tendency of some historians to focus on women undertaking nontraditional roles in the war rather than on the work that most women

71 Jonathan F. Vance, A History of Canadian Culture (Toronto: Oxford University Press, 2009), 241.

72 Gene Allen, Making National News: A History of Canadian Press (Toronto: University of Toronto Press, 2013).

73 Neta Gordon, Catching the Torch: Contemporary Canadian Literary Responses to World War I (Waterloo: Wilfrid Laurier University Press, 2014). For more on the literature on the war and the impact of film, see David Williams, Media, Memory, and the First World War (Montreal: McGill-Queen's University Press, 2009).

74 Peter Webb, "'A Righteous Cause': War Propaganda and Canadian Fiction, 19151921," British Journal of Canadian Studies 24, no. 1 (2011): 31-48. 
actually did - in the homes, factories, and churches.$^{75}$ With respect to voluntary work, Steve Marti has examined how it was shaped and understood based on its scale and the spatial boundaries within which it occurred, leading to conclusions about how "space factored into the construction of identity." 76

In a groundbreaking collection of essays, edited by Sarah Glassford and Amy Shaw, several different aspects of the wartime experiences of primarily English Canadian and Newfoundland women and girls are examined. Their goal was to shed light on the often overlooked aspects of the war and, in particular, the contribution made by women in fundraising, patriotic organizing, volunteer and other charitable activities, and, of course, knitting socks. Each author is an expert in her/his field and together they bring a broad array of sources to their topics, which include nursing sisters, female industrial workers, the Indigenous women of Ontario's Six Nations reserve, the Newfoundland Women's Patriotic Association, and female students at the University of Toronto. The collection also contains chapters on poetry, novels, and medals - the "marks of grief." There are different viewpoints concerning the war's transformative nature, but together these essays make a significant and original contribution to our understanding of women's experience in the war. ${ }^{77}$ In a related way, Suzanne Evans, in Mothers of Heroes, has focused on maternal mourning, grief, and images of "mother," especially those who sacrificed a son in the fight. ${ }^{78}$

The study of the war's impact on children is addressed in the Glassford and Shaw collection, and it is the central focus of Susan Fisher's Boys and Girls in No Man's Land. Fisher explores both the fate of the Canadian child soldiers overseas and the fate of children on the home

75 Amy Shaw, "Expanding the Narrative: A First World War with Women, Children, and Grief," Canadian Historical Review 95, no. 3 (September 2014): 398-406. See also Sarah Glassford, "Women's Mobilization for War (Canada)," in 1914-1918 Online: International Encyclopedia of the First World War, ed. Ute Daniel, Peter Gatrell, Oliver Janz, Heather Jones, Jennifer Keene, Alan Kramer, and Bill Nasson, issued by Freie Universität Berlin, https: / encyclopedia.1914-1918-online.net/home/.

76 Steve Marti, "For Kin and County: Scale, Identity, and English-Canadian Voluntary Societies, 1914-1918," Historie sociale / Social History 47, no. 94 (June 2014): 349.

77 Sarah Glassford and Amy Shaw, eds., A Sisterhood of Suffering and Service: Women and Girls of Canada and Newfoundland during the First World War (Vancouver: UBC Press, 2012).

78 Suzanne Evans, Mothers of Heroes, Mothers of Martyrs: World War I and the Politics of Grief (Montreal: McGill-Queen's University Press, 2007). 
front - the thousands of children who suffered loss, grief, financial hardship, etc., thanks to their fathers or other close relatives serving overseas. Many children went to work - doing family chores as well as volunteer, charitable, and other war-related activities. Fisher extends her work into an examination of how the war has been reflected and remembered in modern children's literature. ${ }^{79}$ Mary Chaktsiris takes a different perspective and highlights the gendered nature of Canada's war effort by looking at the complexity of student reactions to the war, and she demonstrates how even though there was strong support for the war in Toronto and among University of Toronto students there were "voices of discomfort and tiredness," especially the longer the war dragged on ${ }^{80}$

Other voices have become more prominent in recent years as well. Continuing the path established by Brian Titley, James Dempsey, and a few others, Amy Shaw argues that recent research on Indigenous people "challenges earlier presentations of a broad patriotic reaction and emphasizes the variety of First Nations' responses and the degree to which, despite First Nations' participation, unfair treatment persisted after the war." ${ }^{181}$ Much more space is given to Indigenous voices and greater emphasis has been placed on portraying Indigenous people as active agents in their own history - from the personal, community, and economic motivations behind enlistment to the larger questions of identity and rights, and how the wartime experience sparked the movement into political activism in the post-war era through groups such as the League of Indians (established in 1919).

Robert Talbot, for example, challenges some of these earlier ideas, arguing that it was self-interest more than loyalty that prompted the

79 Susan R. Fisher, Boys and Girls in No Man's Land: English-Canadian Children and the First World War (Toronto: University of Toronto Press, 2011).

80 Mary G. Chaktsiris, “'Not Unless Necessary': Student Responses to War Work at the University of Toronto, 1914-1918," Historie sociale / Social History 47, no. 94 (June 2014): 294.

81 Amy Shaw, "Historiography 1918-Today (Canada)," in 1914-1918 Online:

International Encyclopedia of the First World War, ed. Ute Daniel, Peter Gatrell, Oliver Janz, Heather Jones, Jennifer Keene, Alan Kramer, and Bill Nasson, issued by Freie Universität Berlin, https:/ / encyclopedia.1914-1918-online.net/home/. See also Brian Titley, A Narrow Vision: Duncan Campbell Scott and the Administration of Indian Affairs in Canada (Vancouver: UBC Press, 1986); and L. James Dempsey, Warriors of the King: Prairie Indians in World War I (Regina: Canadian Plains Research Center and University of Regina, 1999). 
approximately four thousand Indigenous men to serve in the Canadian military. He highlights examples of "ambivalence and resistance" and concludes that the responses of First Nations were "both similar to and distinct from those of other Canadians." ${ }^{82}$ In two articles, Katherine McGowan looks at how Indigenous communities in southern Ontario and British Columbia responded and challenged recruitment efforts and the Military Service Act. ${ }^{83}$ Karine Duhamel and Matthew McRae have examined the mixed motivations of Indigenous people and how they negotiated their participation in the war, ${ }^{84}$ while Eric Story ventures into the post-war era to illustrate how Indigenous soldiers "consistently used the Great War to further both personal and collective goals of improving the circumstances of their peoples." 85

The most comprehensive examination of Indigenous people and the war is Timothy Winegard's For King and Kanata: Canadian Indians and the First World War. After chapters on the history of Indian policy, racial theories, and Indigenous people in past wars, he surveys the early support for the war, the barriers and growing confusion around enlistment, and the eventual policy change to encourage Indigenous recruitment. About 35 per cent of the eligible Indigenous male population of military age enlisted, roughly the same as in the non-Indigenous population. In the end, the war brought few long-term benefits for Indigenous people. "By its actions and policies," Winegard concludes, "the government of Canada evidently thought Indians worthy enough to fight and

82 Robert J. Talbot, “'It Would Be Best to Leave Us Alone': First Nations Responses to the Canadian War Effort," Journal of Canadian Studies 45, no. 1 (Winter 2011): 92-3.

83 Katherine McGowan, "'In the Interest of the Indians': The Department of Indian Affairs, Charles Cooke and the Recruitment of Native Men in Southern Ontario for the Canadian Expeditionary Force, 1916," Ontario History 102, no. 1 (Spring 2010): 109-24; and "'Until We Receive Just Treatment': The Fight against Conscription in the Naas Agency, British Columbia," BC Studies 167 (Autumn 2010): 47-70. See also her chapter with P. Whitney Lackenbauer, in P. Whitney Lackenbauer and Craig Leslie Mantle, eds., Aboriginal Peoples and the Canadian Military: Historical Perspectives (Kingston, ON: Canadian Defence Academy Press, 2007), 89-115, and the chapter by John Moses, in the same collection.

84 Karine Duhamel and Matthew McRae, "'Holding Their End Up in Splendid Style': Indigenous People and Canada's First World War," Manitoba History 82 (Fall 2016): $41-6$.

85 Eric Story, "'The Awakening Has Come': Canadian First Nations in the Great War Era, 1914-1932," Canadian Military History 24, no. 2 (Summer/Autumn 2015): 14. 
die for Canada when needed, but not worthy enough to enjoy the privileges and rights of Canadian citizens." ${ }^{186}$

The study of the wartime experience of ethnic and racialized minorities and marginalized groups in Canadian society has continued to grow and build upon the pioneering work of Donald Avery, Bohdan Kordan, and others. ${ }^{87}$ In "The Predicament of Belonging," James Farney and Bohdan Kordan explore the deep conflict between citizenship and Britishness among "enemy aliens" in the early war years and they raise important questions about the nature of citizenship in Canada in a situation where immigrants could be naturalized as Canadians but not acquire British subject status. This "problematic status," they argue, led to confusion about the rights of "enemy alien" civilians and was used as justification by the government to intern several thousand of them as military POWs..$^{88}$ In No Free Man, Kordan provides the most comprehensive examination - public attitudes about loyalty, government policy, the internment experience - of the "problem" of enemy aliens. ${ }^{89}$ Taking a slightly different perspective, Nathan Smith has looked at the anti-alien activism of returned soldiers and, especially, the Great War Veterans' Association. ${ }^{90}$

In "Be British or Be D-d," Mario Nathan Coschi examines identity and citizenship as it was played out on the local level through attempts to enforce Anglo conformity on Berlin/Kitchener's largely ethnically German community. These forces could be found at work elsewhere

86 Timothy C. Winegard, For King and Kanata: Canadian Indians and the First World War (Winnipeg: University of Manitoba Press, 2012), 167. See also note 32.

87 Donald Avery, 'Dangerous Foreigners': European Immigrant Workers and Labour Radicalism in Canada, 1896-1932 (Toronto: McClelland and Stewart, 1979); and Bohdan S. Kordan, Enemy Aliens, Prisoners of War: Internment in Canada during the Great War (Montreal: McGill-Queen's University Press, 2002).

88 James Farney and Bohdan S. Kordan, "The Predicament of Belonging: The Status of Enemy Aliens in Canada, 1914," Journal of Canadian Studies 39, no. 1 (Winter 2005): 75.

89 Bohdan S. Kordan, No Free Man: Canada, the Great War, and the Enemy Alien Experience (Montreal: McGill-Queen's University Press, 2016). See also Lubomyr Luciuk, Without Just Cause (Kingston: Kashtan Press, 2006); George Buri, "'Enemies within Our Gates': Brandon's Alien Detention Centre during the Great War," Manitoba History 56 (October 2007): 3-11.

90 Nathan Smith, "Fighting the Alien Problem in a British Country: Returned Soldiers and Anti-alien Activism in Wartime Canada, 1916-19," in Other Combatants, Other Fronts: Competing Histories of the First World War, ed. James Kitchen, Alisa Miller, and Laura Rowe (Newcastle, UK: Cambridge Scholars Publishing, 2011), 293-318. 
in the country and this essay is a good local case study of a national issue. ${ }^{91}$ Race relations are examined by Greg Marquis in his examination of the Canadian response to the wartime screening of the American film The Birth of a Nation and, in particular, how the African-Canadian community in several major cities protested the film and unsuccessfully appealed to the authorities to have some of its most racially charged parts censored. While white audiences generally welcomed and approved of the film, African-Canadians condemned its overt racism and positive portrayal of the Ku Klux Klan and appealed to other Canadians by playing on their patriotism and sense of fair play - but without success. ${ }^{92}$ Moreover, Lyle Dick challenges us to reconsider how we remember the war through his examination of the struggle for rights and recognition of Japanese-Canadian veterans. ${ }^{93}$

The last dozen years have also seen a shift in emphasis away from regional or provincial histories to examinations of the war's impact on major Canadian cities, building on the work of Ian Miller and Robert Rutherdale. ${ }^{94}$ Most of these recent city-histories are less investigations into the realm of urban history than they are snapshots of how the war impacted the particular city itself. All focus on the local war effort, but their stories can never be divorced from the national narrative. Each city had its recruitment of local men, was impacted by rapid economic and social change, and responded to the conscription crisis and the 1917 election. In most cases, the people of one city responded to the war as the people in other cities did, with a few regional variations

91 Mario Nathan Coschi, “'Be British or Be D-d': Primary Education in Berlin-Kitchener, Ontario, during the First World War," Histoire sociale / Social History 47, no. 94 (June 2014): 311-32.

92 Greg Marquis, "A War within a War: Canadian Reactions to D. W. Griffith's The Birth of a Nation," Histoire sociale / Social History 47, no. 94 (June 2014): 421-42. Another essay in the same journal issue examines how racist attitudes in the United Kingdom, United States, and Canada extended into the post-war era: Peter Campbell, "'Black Horror on the Rhine': Idealism, Pacifism, and Racism in Feminism and the Left in the Aftermath of the First World War," Histoire sociale / Social History 47, no. 94 (June 2014): 471-93.

93 Lyle Dick, "Sergeant Masumi Mitsui and the Japanese Canadian War Memorial: Intersections of National, Cultural, and Personal Memory," Canadian Historical Review 91, no. 3 (September 2010): 435-63.

94 Ian Hugh Maclean Miller, Our Glory and Our Grief: Torontonians and the Great War (Toronto: University of Toronto Press, 2002); Robert Rutherdale, Hometown Horizons: Local Responses to Canada's Great War (Vancouver: UBC Press, 2004). 
- patriotically at first but, as the war continued and the casualties rose, support for the war eroded, especially among native-born Canadians. In the meantime they volunteered, worked, suffered and grieved, lived and died.

Terry Copp has produced an innovative online and interactive history of Montreal and Montrealers at war. The initial enthusiasm is there, and overseas service is documented, with Montrealers fighting at Ypres, Festubert, Courcelette, Vimy, and elsewhere, but soon difficulties arose in filling French-Canadian regiments. Montreal appears as a much-divided city, primarily, but not exclusively, along linguistic lines, and Copp explains how Ontario's Regulation 17 enflamed the conscription debate in Montreal, leading to rising protests in the summer of 1917. Copp is careful not to separate the war situation overseas and events in Montreal, especially in the lead-up to the 1917 federal election campaign. The result of the vote was never in doubt; the impact on an already divided city, though, was incalculable..$^{95}$

Haligonians have been somewhat less well served by historians, not because of a lack of a wartime history but more as a result of the fixation on the 1917 Halifax explosion. It has long dominated the literature, and the attention only heightened as the centenary of the tragedy approached, with two new works appearing to coincide with the anniversary. ${ }^{96}$ To the west, Windsor, Ontario, is the focus of Brandon Dimmel's "Sabotage, Security, and Border-Crossing Culture." The article revolves around a June 1915 explosion at the local Peabody Overall Factory and its impact on the community. Windsor was economically and culturally dependent on Detroit (with more than two dozen American-owned companies in the city), and when Ottawa raised the threat level and began taking precautions to protect the border, cross-border traffic was inevitably negatively affected, angering the local population and city council. The whole affair heightened concerns at the border, as well, not only over potential saboteurs but also over "enemy aliens" who might

95 Terry Copp, Montreal at War 1914-1918: A History of Canada's Metropolis at War (Waterloo: Laurier Centre for Military Strategic and Disarmament Studies, Wilfrid Laurier University, 2017).

96 Ken Cuthbertson, The Halifax Explosion: Canada's Worst Disaster December 6, 1917 (Toronto: Harper Collins, 2017); John U. Bacon, The Great Halifax Explosion: A World War I Story of Treachery, Tragedy, and Extraordinary Heroism (New York: Harper Collins, 2017). 
slip into the United States en route to their homelands where they could turn into enemies on the battlefield and, conversely, over the possibility of Canadians fleeing south to avoid conscription. ${ }^{97}$

In the west there were regional differences and regional complaints, especially over the tariff and the awarding of contracts mainly to central Canadian businesses. Conscription played out it in its own way, as did the temperance and suffrage movements, and the "conscription of wealth" took on important class and regional meanings. James Pitsula explores these issues in For All We Have and Are, a history of wartime Regina. Pitsula looks at how Regina played its role as the hub for a largely rural area, where the Social Gospel still resonated and ethnic tensions ran high between the Anglo elite that held the power and the non-British population that did the manual labour. Pitsula discusses the "rural myth" that combined confidence in the future growth of the region's agricultural production and the patriotic dedication to growing as much food as possible. Regina was at the centre of this myth, in a province where "In Wheat We Trust" was more than just a slogan. "More than ever," Pitsula concludes, "agriculture was destiny."

In Winnipeg's Great War, Jim Blanchard provides a local comingof-age story in his examination of the war's impact on the economy, people, social welfare services, volunteer work, and municipal and provincial politics of Canada's third-largest city. Class divisions were particularly strong here and played a role in the growing labour unrest and demands for relief from the municipal government. Blanchard devotes considerable attention to the large Ukrainian and Polish communities, many members of which offered to serve during the war but also fell under suspicion as foreigners and "enemy aliens." As is the case with other city-histories, Winnipeg's war is very much tied to the larger experience - suffrage, enlistment and conscription, the federal election, the income tax, Armistice Day, and the flu epidemic - and the text shifts focus from local to national and international developments. Still, at the end of the war Winnipeg was no longer the "brash and overconfident

97 Brandon Dimmel, "Sabotage, Security, and Border-Crossing Culture: The Detroit River during the First World War, 1914-1918," Histoire sociale / Social History 47, no. 94 (June 2014): 401-19.

98 James Pitsula, For All We Have and Are: Regina and the Experience of the Great War (Winnipeg: University of Manitoba Press, 2008), 279. 
place" that it was in 1914; rather, it was a "more cautious and conservative place" with a new path to the future. ${ }^{99}$

\section{The Aftermath}

Canada's diplomatic and international role in the ending of the war and the beginning of the peace has not been the focus of much recent historical interest beyond the few works mentioned above. Much more attention has been paid to the devastating flu epidemic of 1918-19, thanks, perhaps, to recent concerns over the advent of modern epidemics ranging from Bird Flu to SARS. In Influenza 1918, Esyllt Jones investigates how Winnipeggers responded to the epidemic and how issues of class and poverty became factors as factories were closed and quarantined and people were thrown out of work. Several of these themes are reexamined in the multiple case studies in Fahrni and Jones' edited collection: Epidemic Encounters. ${ }^{100}$ Mark Osborne Humphries, in The Last Plague, traces the spread of the flu, the efforts to contain it, the challenges that it created for the fledgling public health system, and the impact that it had on communities across the country. ${ }^{101}$ Humphries focuses more on the response of the federal government and examines the impact of the epidemic on the formation of public health policy; Jones looks more at the flu's impact on one city and how it combined with and exacerbated sharp class tensions, thereby contributing to the eruption of the Winnipeg General Strike in 1919.

Beginning at the end of the war, Alan Bowker, in A Time Such as There Never Was Before, looks at the new Canada created by the war - the economic growth, the social reforms (including women's suffrage), the growing role of government (bureaucracy, regulation, taxation, etc.) and the linguistic divisions and anti-foreigner and anti-Bolshevik fever that remained. Generally optimistic, Canadians comprised a mixture of hope and fear - "fear of the future, fear of Bolshevism, fear of moral decline, fear of the stranger, fear of the loss of old ideals and values, fear

99 Jim Blanchard, Winnipeg's Great War: A City Comes of Age (Winnipeg: University of Manitoba Press, 2010), 267.

100 Esyllt Jones, Influenza 1918: Disease, Death, and Struggle in Winnipeg (Toronto: University of Toronto Press, 2007); Magda Fahrni and Esyllt W. Jones, eds., Epidemic Encounters: Influenza, Society, and Culture in Canada, 1918-20 (Vancouver: UBC Press, 2012).

101 Mark Osborne Humphries, The Last Plague: Spanish Influenza and the Politics of Public Health in Canada (Toronto: University of Toronto Press, 2013). 
that the new Europe for which the soldiers had died was already collapsing in violence and revolution." 102 One of the few works that looks at the impact of the war and is aimed at the general reader, Bowker captures some of the ambivalence and anxiety that permeated Canadian society at the start of a new era.

As we move further away from the war it is perhaps not that surprising that more work has appeared comparing experiences between the First and Second World Wars. By focusing on the two, wars historians have had the opportunity to compare and contrast the wartime experience, the social impact of the wars, and what lessons may - or may not - have been learned in the intervening decades. This is the goal of Andrew Iarocci and Jeffrey Keshen in A Nation in Conflict: Canada and the Two World Wars. In several chapters (including separate chapters for the army, navy, and air force) they seek common themes running through Canada's two world wars - recruitment, accelerated industrialization, the role of government, how the war inspired patriotism among some and provoked deep divisions among others, and how the wars ultimately changed Canada's place in the world. They conclude that Canada emerged from the second war in a far stronger position wealthier, more established, and peaceful - compared to the dislocation of the first, thanks to the social turmoil of labour unrest, the flu epidemic, and the anti-conscription riots in Quebec. ${ }^{103}$

In Warlords, Tim Cook looks specifically - but separately - at the wartime leadership of Robert Borden and Mackenzie King. Although one would not initially think of Borden as a "warlord," he is shown to have evolved from a dull, even plodding, head of a rather ineffective government into a tough leader who, armed with the War Measures Act, was willing to rearrange the electorate in 1917 to guarantee his party's victory, to quash rural and labour dissent, and to enforce conscription over the angry complaints of a large part of the country. Comparing the two leaders is not Cook's primary goal, but whenever he does, King almost always comes out ahead. Given that he had Borden and his mistakes to learn from, King was able to avoid the worst excesses of the first war, especially when it came to handling the divisive issue of conscription. ${ }^{104}$

102 Alan Bowker, A Time Such as There Never Was Before (Toronto: Dundurn, 2014), 35.

103 Andrew Iarocci and Jeffrey A. Keshen, A Nation in Conflict: Canada and the Two World Wars (Toronto: University of Toronto Press, 2015).

104 Tim Cook, Warlords: Borden, Mackenzie King, and Canada's World Wars (Toronto: Allen Lane, 2012). 
Taking a slightly different perspective, Jonathan Vance looks at the impact of the over one million Canadians who were stationed in the United Kingdom during the two world wars in Maple Leaf Empire. This is an examination of "Britishness" and what Vance calls a "kind of reverse colonialism," as Canadians established a number of "outposts" in the United Kingdom and, in their own small way, Canadianized the local communities. ${ }^{105}$ Clearly, by 1939 the excitement of 1914 was long gone. Luke Flanagan looks at the experience of Canadian soldiers training in a small British town sixty miles south of London and essentially supports Vance's idea of "reverse colonialism," and he argues that the movement toward nationhood was more nuanced than generally understood, as it was done within a context of continued attachment to the empire. "Imperialism and attachment to Canada were compatible," he concludes. ${ }^{106}$

In an ambitious and innovative study entitled Living with War, Robert Teigrob examines how war has been remembered in Canada and the United States across the twentieth century and suggests that Canadians have been more warlike (in the way they recall their wars) and Americans less warlike (or at least more critical of their wars) than commonly remembered. While the book is more a study in CanadianAmerican relations than a comparison of the two world wars, Teigrob does take issue with the idea of the First World War as a moment of national founding, and he demonstrates how that same epitaph had been applied to other, earlier wars as well. ${ }^{107}$ Canadians more than Americans, he concludes, have tended to uncritically accept the official narrative about their wars as positive experiences that have led to the growth and strengthening of the nation.

105 Jonathan Vance, Maple Leaf Empire: Canada, Britain, and Two World Wars (Toronto: Oxford University Press, 2012), 4.

106 Luke Flanagan, "Canadians in Bexhill-on-Sea during the First World War: A Reflection of Canadian Nationhood?" British Journal of Canadian Studies 27, no. 2 (2014): 131. One area that experienced little change was the depiction of corpses in official war art. See Laura Brandon, "Above or Below Ground? Depicting Corpses in First and Second World War Official Canadian War Art," in Bearing Witness: Perspectives on War and Peace from the Arts and Humanities, ed. Sherrill Grace, Patrick Imbert, and Tiffany Johnstone (Montreal: McGill-Queen's University Press, 2012) 93-106.

107 Robert Teigrob, Living with War: Twentieth-Century Conflict in Canadian and American History and Memory (Toronto: University of Toronto Press, 2016), 303-9. 
Equally, what we remember and what should be acknowledged, if not celebrated, during the war's centenary is still an area of considerable disagreement. In a brief chapter in a book on nationalism, Alan Gordon compares the memory of the war in French and English Canada. Both groups honoured the victory, but wartime divisions - especially over conscription - remained in the post-war era. Gordon traces the emergence of a new nationalism in Quebec and discusses how war monuments in Quebec have tended to be less celebratory, honouring French-Canadian victims as well as veterans. ${ }^{108}$ Christopher Moore is critical of the lack of debate over why Canada entered the war in the first place. It was understood - then and now - that when Britain was at war Canada was at war; however, as an autonomous nation Canada preserved the right not to participate in any significant way. The absence of debate over causes and consequences leads us to focus on the violence, suffering, and loss experienced during the war. ${ }^{109}$ Tim Cook further suggests that historians add to what he calls the three dominant narratives of the war - the slaughter and loss, the birth of nationalism, and the fractures the war created - by focusing more attention on the "absent war," including the near million eligible men who chose not to enlist. "If we are to remember the more than 620,000 Canadians who enlisted," he argues, "we must also fashion a new understanding of why at least double that many males refused to serve."110

Much of the way Canadians remember the war and talk about it revolves around the Battle of Vimy Ridge, and this conversation only intensified with the approach of the battle's centenary in 2017. Everyone has had something to say about Vimy, ranging from popular histories, to the Canadian War Museum, to a play about four wounded soldiers (from different parts of the country and of different ethnicities)

108 Alan Gordon, "Lest We Forget: Two Solitudes in War and Memory," in Canadas of the Mind: The Making and Unmaking of Canadian Nationalisms in the Twentieth Century, ed. Norman Hillmer and Adam Chapnick (Montreal: McGill-Queen's University Press, 2007), 159-73. See also Kellen Kurschinski, Steve Marti, Alicia Robinet, Matt Symes, and Jonathan F. Vance, eds., The Great War: From Memory to History (Waterloo: Wilfrid Laurier University Press, 2015).

109 Christopher Moore, "1914 in 2014: What We Commemorate When We Commemorate the First World War, Canadian Historical Review 95, no. 3 (September 2014): $427-32$.

110 Tim Cook, "Battles of the Imagined Past: Canada's Great War and Memory," Canadian Historical Review 95, no. 3 (September 2014): 421. 
recuperating in hospital after the battle. ${ }^{111}$ In a lengthy and oversized book, Michael Krawchuk, a non-academic historian with a love for military history, has produced a detailed examination of the preparations, the context, and the battle itself. Krawchuk places his battle very much in the context of nation building with Vimy playing a large part in Canada's transformation. "From Vimy," he writes, "the Canadian Corps and Canada as a nation took the path toward true nationhood."

The Vimy monument, at the centre of considerable national attention in 2017, has also received critical scrutiny, although, even here, the divisions over its meaning remain deep. Jacqueline Hucker traces the origins and construction of the monument as a sacred site, and she shows how it evolved from a spiritual place into a historical site in the 1960s and 1970s, through to its modern restoration in the years leading up to the centenary. ${ }^{113}$ Dennis Duffy has assessed the cultural impact of the monument and its effort to assert a national presence. ${ }^{114}$ At the same time, Jeremy Diamond has reasserted how strong the memory of this nation-changing event has remained. That day in April all Canadians were united as one, just like the soldiers on the battlefield; Vimy was a "milestone where Canada came of age and was then recognized on the world stage."115

The last decade has seen a ramping up of the debate over the meaning of Vimy as a "coming-of-age" story. The first major "reassessment" - Vimy Ridge: A Canadian Reassessment - comprises multiple chapters on the Corps, the divisions, the leadership, the strategic context, the enemy, and the aftermath, written by a who's who of the leading scholars

111 See Peter Barton, with Jeremy Banning, Vimy Ridge and Arras: The Spring 1917 Offensive in Panoramas (Toronto: Dundurn Press, 2010); "Vimy: The History of an Idea," Queen's Quarterly 124, no. 2 (Summer 2017): 184-99; Vern Thiessen, Vimy (Toronto: Playwrights Canada Press, 2007).

112 Michael Krawchuk, The Battle of Vimy Ridge: Wall of Fire (Calgary: Detselig Enterprises, 2009), 380. See also Ted Barris, Victory at Vimy: Canada Comes of Age, April 9-12, 1917 (Toronto: Thomas Allen, 2007).

113 Jacqueline Hucker, "'Battle and Burial': Recapturing the Cultural Meaning of Canada's National Memorial on Vimy Ridge," The Public Historian 31, no. 1 (February 2009): 89-109.

114 Dennis Duffy, "An Ideal Solution: Sculptural Politics, Canada's Vimy Memorial, and the Rhetoric of Nationalism," Mosaic 43, no. 2 (June 2010): 167-84.

115 Jeremy Diamond, "Vimy Ridge Monument: Part of Canadian Identity and Culture," Canadian Issues (Fall 2015): 9. 
on the topic. Together they raise important questions about the actual significance of the battle and challenge many of the elements of the Vimy "myth" that still resonate today. ${ }^{116}$ In addition, in the months before the centenary, two new books took direct aim at the topic: Tim Cook's Vimy and Ian McKay and Jamie Swift's The Vimy Trap. Cook provides a detailed description of the battle and its impact and the building of the monument, and he concludes with an examination of how the battle has been remembered, disputed, and used by subsequent generations. ${ }^{117}$ McKay and Swift directly tackle the issue of Canada being "born" at Vimy, adding the word "Vimyism" to our vocabulary. They see the war as nothing but a terrible and gruesome tragedy and see no evidence of the war as a noble crusade or that "Canadian wars are exercises in selfless sacrifice, struggles for freedom." the time that "we succeeded where others failed," and they argue against the idea that such "martial nationalism" inspired character or epitomized Canadian values.

Despite some heated rhetoric in review sections after these two books appeared, there are elements of commonality. Most observers agree that the "coming-of-age" aspect of Vimy appeared only long after the event - it was not there at the time or in the monument, and Vimy itself was shuffled off into the background during and after the "good" Second World War. Only in the 1960s and more recently (McKay and Swift give considerable credit to the 1986 publication of Pierre Berton's Vimy) did renewed interest in Vimy arise. Given the disillusionment caused by the war - along with the ethnic, racial, and class divisions; the riots; internment; censorship; and dislocation and turmoil - it is hard to see Canada's war as a force for national unity or greatness. Perhaps most can agree with Cook's simple observation that Canada was "forever changed by the Great War, but Vimy did not make the nation. It was the nation that made Vimy."119

116 Geoffrey Hayes, Andrew Iarocci, and Mike Bechthold, eds., Vimy Ridge: A Canadian Reassessment (Waterloo: Wilfrid Laurier University Press, 2007).

117 Tim Cook, Vimy: The Battle and the Legend (Toronto: Allen Lane, 2017).

118 Ian McKay and Jamie Swift, The Vimy Trap: Or, How We Learned to Stop Worrying and Love the Great War (Toronto: Between the Lines, 2016), 17.

119 Cook, Vimy, 384. 
American historian Michael S. Neiberg has urged historians to adopt a more transnational approach to our study of the First World War. He doesn't suggest that the "national model" is without value, but he argues that much more of the complexity of the war could be understood if we adopted an approach that shifts national governments from centre focus and instead examines those features shared by people of different nations (industrialization, imperialism, socialism, and so forth). He singles Canada out as one of those nations that has come to see the war as a kind of formative national experience; but what if we viewed Canada as part "of a much wider world with a shared culture, a shared economic market, and a shared global outlook?"120

However valuable such an approach may be, with a few exceptions mentioned above, it is hard to see a trend to transnationalism in Canadian historiography of the First World War in the last thirteen years. Indeed, the national model and the question of national transformation, which we made the major theme of the first edition of this book, remain at the heart of recent work on Canada and the war. Still, great steps forward have been made in teasing out the meaning of the war; in crossing the old boundaries between military and social history, official and academic history, the Western Front and the home front; and in our understanding of how the war broke along class, racial, gender, linguistic, regional, and political lines. And yet, the more research that is undertaken the more complex the study of the war appears, not surprisingly perhaps, in a country that is so large and with a population so diverse.

Since this book first appeared Robert Craig Brown has passed away and, soon after, so did his good friend and one of our contributors, Ramsay Cook. These two historians - authors of Canada: A Nation Transformed - would be gratified to know that their work continues to be read and discussed today. Our hope is that the essays in this new edition of Canada and the First World War will also make a small contribution to the ongoing re-examination of Canada's experience in the First World War and, hopefully, lead to further research in the years ahead.

120 Michael S. Neiberg, "Toward a Transnational History of World War I" Canadian Military History 17, no. 3 (Summer 2008): 33. 
